\title{
Special Aspects of Work Motivation of Manual Laborers
}

\author{
Dzhaneryan Svetlana Tigranovna ${ }^{1}$, Gvozdeva Darya Ivanovna ${ }^{1, *}$ and Gabdulina
}

\author{
Lyudmila Ivanovna ${ }^{1}$
}

\author{
${ }^{1}$ Southern Federal University, Rostov-on-Don, 344000, Russia \\ *Corresponding author. Email: darya-gvozdeva@yandex.ru
}

\begin{abstract}
The purpose of the study was to research the types of motivation for professional activity, motivational factors, values, and motivational types of manual laborers. The study was conducted using testing methods ("Motivation for professional activity" (K. Zamfir [modification of A. Rean]), "Motivational profile" (S. Ritchie and P. Martin), "Methods for diagnosing labor motives" (V. I. Gerchikov), "Value orientations" (M. Rokich)) and statistical data processing (Friedman, Wilcoxon, binomial distribution criteria). The results of the study showed that motivational characteristics of manual laborers manifested in their dominant motives, motivational factors of professional activity, and motivational types. Dominant values varied in relation to work experience. At the early stages of work-life, employees were characterized by internal personal motivation for work, at later stages - by external positive motivation. Individualistic orientation was typical of employees with little work experience and orientation to socially useful things - of those with longer work experience. The instrumental motivational type included employees with 4-5 years of experience, the lumpenized type -19-20 years, and the patriotic type - 30 years or more. The obtained results can be used in the work of personnel departments of industrial enterprises in the development of individual motivation of manual labor employees.
\end{abstract}

Keywords: motivation, motivational factors, manual laborers, values, motivational type

\section{INTRODUCTION}

In modern world science, there is a stable interest of researchers in the problem of personnel motivation, which is confirmed by a large number of publications reflecting the results of research in this area. The interest of researchers is fueled by the current demands of the modern labor market characterized by a high degree of dependence on social, economic, and political changes in society.

Thus, economic crises lead to the need to optimize the work of enterprises, which implies the reduction of positions and the introduction of new functionality for employees among necessary measures. This, in turn, forces one to review existing systems of motivation. Of particular importance in this situation is non-monetary motivation, the competent use of which allows not only keeping employees motivated but also reducing the financial costs of an enterprise.

On the other hand, orientation to world practices and changing needs of the population leads to the emergence of new types of jobs and determines the demand for specialists in the labor market and the prestige of specific jobs. This, in turn, determines motivation for the professional choice of individuals. The pursuit of the prestige of a job creates a certain "skew" in the number of specialists in certain areas, while other areas of the real economy that are no less important for the country experience a shortage of highly qualified specialists. One of the leading roles in solving such problems is played by building an adequate system of personnel motivation that takes into account both the specifics of an enterprise and the personal characteristics of employees.

The problem of maintaining employee motivation is particularly acute in industrial enterprises, the specifics of which involve the presence of manual labor specialists (repairmen, machine operators, electric and gas welders, machine tool adjusters, etc.). During a certain period, people's interest in these professions was significantly reduced, which led to a decrease in motivation for choosing these professions, as well as a shortage of specialists in the labor market and their significant turnover at enterprises. In this regard, the aspects of labor motivation of manual laborers have not often become the subject of scientific research, compared to a deeper study of the motivational features of students, teachers, and entrepreneurs [1, 7]. Currently, the Russian government, in cooperation with leading scientists and representatives of industrial enterprises, is making efforts to repair the shortage of such specialists (as well as specialists of all technical jobs), which leads to a review of the existing system of their training [3] and development of solutions for creating programs for systematic training of technical specialists based on the principle "school-vocational schoolenterprise" [4]. It is likely that training and support of technical specialists, including specialists of manual labor, is also relevant for other countries, which is reflected in scientific research into the reasons for the resignation of specialists (and students of vocational schools) working in 
the area of technical service and maintenance [8]; development of programs to optimize the formation of engineering and practical skills in students [2]; construction of models of interactions of schools, Master's programs, and enterprises in engineering training of applied technical professionals [5].

In any system of training, the success of the professional activity of manual laborers largely depends not only on the acquired professional skills but also on a well-designed system of their motivation in the organization. Understanding the motivational aspects of this category of workers will allow employees of personnel departments of enterprises to reduce the risk of losing specialists. Therefore, the study of the aspects of the motivation for manual labor is relevant for modern society and science.

\section{PURPOSE, SUBJECT, AND SAMPLE OF THE STUDY}

\subsection{Purpose and subject of the study}

Based on the above-mentioned theoretical assumptions, we conducted research aimed at studying the types of motivation in professional activity, motivational factors, values, as well as the motivational types of manual laborers with different work experience.

The subject of the research was the peculiar aspects of labor motivation of manual laborers.

\subsection{Sample description of the research}

Our research involved 100 employees of one of the Russian industrial enterprises aged 24 to 65 years old. All respondents were male. They represented the following working professions: repairmen, machine operators (turner, milling machine operator), electric and gas welders, and machine tool adjusters.

The workers who participated in the research were divided into five groups by the period of their work at the enterprise: employees, whose working period was 5 (32 people), 10 (27 people) 20 (16 people), 30 (16 people), and 40 (9 people) years.

\section{PROBLEMS AND METHODOLOGY}

Our research was aimed at obtaining data that would allow us to get closer to solving the problem of retention of manual labor specialists by maintaining their motivation for work at an enterprise. In a situation of piece-rate basis, in which financial remuneration directly depends on the specifically measured result of work, monetary motivation acts as an independent motivational mechanism. However, monetary motivation may not be enough to keep an employee motivated to work, which is due to several factors. Firstly, the phenomenon of "addiction" to the income level manifested in a tendency to devalue the level of previously increased income to the level of familiar, which, when used as sole monetary motivation, leads to a periodic increase in remuneration of the employee and increases costs for the enterprise. Secondly, each employee has individual motives that are quite stable and determine the nature of their work behavior and activities, individual needs that determine the employee's job satisfaction and expectations regarding working conditions (including the incentive system), as well as individual values, inability to follow which leads to a significant decrease in motivation for work.

The research was conducted using testing methods and statistical data processing. To diagnose motivational aspects of the individuals, the following methods were used: "Motivation for professional activity" (K. Zamfir [modification of A. Rean]), "Motivational profile" (S. Ritchie and P. Martin), "Methods for diagnosing labor motives" (V. I. Gerchikov), "Value orientations" (M. Rokich). Empirical results of the research were processed using the D. W. Owen binomial criterion and the methods of nonparametric statistics: the Friedman and Wilcoxon criteria. The Friedman criterion was used to establish leading motivation measurement, and the Wilcoxon criterion was used to confirm differences in dominance. The $\mathrm{p} \leqslant 0.05$ level was chosen as significant.

In each group formed based on the length of work experience of employees, we established the type of motivation for professional activity, motivational factors, values, and motivational types of employees.

Internal, external positive, and external negative motivations were considered as types of professional activity motivation. According to the motivational theory of S. Ritchie and P. Martin, workers are motivated by the need for high wages and material remuneration; the need for good working conditions and a comfortable environment; the need for clear structuring of work; the need for social contacts; the need to form and maintain long-term, stable relationships that involve a significant degree of closeness and trust; the need to gain recognition by other people; the need to set complex goals for oneself and achieve them; the need for influence and power; the need for diversity and change; the need to be creative, analyzing, and thinking employee, open to new ideas; the need for self-improvement, growth, and development as a person; the need for interesting and socially useful work. As values, we studied terminal and instrumental values proposed by M. Rokich. According to V. I. Gerchikov's model of labor motivation, motivational types of employees included instrumental, economic, patriotic, lumpenized, and professional types [6].

\section{RESULTS AND DISCUSSION}

The results of our research showed that manual workers with 4-5 years of experience were characterized by internal motivation and professional activity and can also be 
attributed to the instrumental motivational type (Table 1), in which labor is regarded as a tool to achieve other needs, not related to labor itself, and there is a focus on achieving specific and measurable results. The leading motivational factors are the need for recognition, self-improvement, communication, achievement of high goals, and decent remuneration. Along with this, the motivation of the respondents in this group was supported by their interest in the work itself (terminal value), accompanied by a demonstration of good breeding (instrumental value).

Table 1 Motivational types of manual workers with 4-5 years' experience

\begin{tabular}{|c|c|c|c|}
\hline $\begin{array}{l}\text { Motivational } \\
\text { types of } \\
\text { workers }\end{array}$ & $\begin{array}{c}\text { Sum of } \\
\text { ranks }\end{array}$ & $\begin{array}{c}\mathrm{X}^{2} \\
\text { Friedman } \\
\text { ANOVA }\end{array}$ & $\begin{array}{c}\text { Wilcoxon } \\
\text { Matched } \\
\text { Pairs Test }\end{array}$ \\
\hline instrumental & 114.5000 & \multirow{5}{*}{$\begin{array}{l}46.59785 \\
p<0.0000\end{array}$} & \multirow{5}{*}{$\begin{array}{l}\text { T-13.5000, } \\
p<0.000244\end{array}$} \\
\hline professional & 86.0000 & & \\
\hline lumpenized & 79.0000 & & \\
\hline economic & 67.0000 & & \\
\hline patriotic & 43.5000 & & \\
\hline
\end{tabular}

Manual workers with 8-10 years of work experience were characterized by external positive motivation for professional activity and can also be classified as instrumental (described above) and economic (assuming full responsibility for their work, autonomy in decisionmaking, and non-acceptance of third-party control) motivational types (Table 2). The leading motivational factor is the need for power. At the same time, the motivation of the respondents in this group was supported by the ability to develop, receive recognition from colleagues and superiors (terminal values), as well as orientation to the values of a successful enterprise and selfaffirmation (instrumental values).

Table 2 Motivational types of manual workers with 8-10 years' experience

\begin{tabular}{|c|c|c|c|}
\hline $\begin{array}{c}\text { Motivational } \\
\text { types of } \\
\text { workers }\end{array}$ & $\begin{array}{c}\text { Sum of } \\
\text { ranks }\end{array}$ & $\begin{array}{c}\mathrm{X}^{2} \\
\text { Friedman } \\
\text { ANOVA }\end{array}$ & $\begin{array}{c}\text { Wilcoxon } \\
\text { Matched } \\
\text { Pairs Test }\end{array}$ \\
\hline instrumental & 40.50000 & \multirow{5}{*}{$\begin{array}{l}12.73514, \\
p<0.01265\end{array}$} & \multirow{5}{*}{$\begin{array}{l}\text { T-3.5000, } \\
p<0.024391\end{array}$} \\
\hline economic & 38.00000 & & \\
\hline professional & 25.50000 & & \\
\hline lumpenized & 24.00000 & & \\
\hline patriotic & 22.00000 & & \\
\hline
\end{tabular}

Manual laborers with 19-20 years of work experience were characterized by external negative motivation for professional activity and can also be classified as the lumpenized motivational type, characterized by low motivation to work in general, focus on avoiding punishment, and low activity (Table 3 ). The leading motivational factors are the need for change and establishing contacts. At the same time, the respondents in this group are motivated to work by the ability to be free and act in accordance with their worldview (terminal values), as well as to be guided by ethical values and values of communication (instrumental values).

Table 3 Motivational types of manual workers with 19-20 years' experience

\begin{tabular}{|c|c|c|c|}
\hline $\begin{array}{c}\text { Motivational } \\
\text { types of } \\
\text { workers }\end{array}$ & $\begin{array}{c}\text { Sum of } \\
\text { ranks }\end{array}$ & $\begin{array}{c}\mathbf{X}^{2} \\
\text { Friedman } \\
\text { ANOVA }\end{array}$ & $\begin{array}{l}\text { Wilcoxon } \\
\text { Matched } \\
\text { Pairs Test }\end{array}$ \\
\hline lumpenized & 112.50000 & \multirow{5}{*}{$\begin{array}{l}47.28974, \\
p<0.0000\end{array}$} & \multirow{5}{*}{$\begin{array}{l}\mathrm{T}-14.5000 \\
\mathrm{p}<0.0000126\end{array}$} \\
\hline instrumental & 71.00000 & & \\
\hline professional & 69.50000 & & \\
\hline economic & 62.00000 & & \\
\hline patriotic & 48.00000 & & \\
\hline
\end{tabular}

Manual laborers with 29-30 years of work experience are characterized by external positive motivation for professional activity and can also be classified as lumpenized (described above) and patriotic (importance of public recognition in the organization, willingness to serve the organization) motivational types (Table 4). The leading motivational factors are the need for change and socially useful work. At the same time, the motivation for work in this group of the respondents is supported by the presence of full, active work activity and the ability to act in accordance with their worldview (terminal values), as well as an orientation to ethical values.

Table 4 Motivational types of manual workers with 29-30 years' experience

\begin{tabular}{|c|c|c|c|}
\hline $\begin{array}{c}\text { Motivational } \\
\text { types of } \\
\text { workers }\end{array}$ & $\begin{array}{c}\text { Sum of } \\
\text { ranks }\end{array}$ & $\begin{array}{c}\mathrm{X}^{2} \\
\text { Friedman } \\
\text { ANOVA }\end{array}$ & $\begin{array}{l}\text { Wilcoxon } \\
\text { Matched } \\
\text { Pairs Test }\end{array}$ \\
\hline lumpenized & 42.50000 & \multirow{5}{*}{$\begin{array}{l}11.75629, \\
p<0.02246\end{array}$} & \multirow{5}{*}{$\begin{array}{l}\text { T-4.5000, } \\
p<0.019845\end{array}$} \\
\hline patriotic & 36.00000 & & \\
\hline professional & 22.00000 & & \\
\hline economic & 21.50000 & & \\
\hline instrumental & 19.00000 & & \\
\hline
\end{tabular}

Manual laborers with 39-40 years of work experience were characterized by external positive motivation for professional activity and can also be attributed to the patriotic motivational type (Table 5). The leading motivation factors are the need for decent remuneration and socially useful work. Along with this, the motivation of the respondents in this group was supported by their ability to be free and develop (terminal values), accompanied by the implementation of ethical values and values of a successful enterprise (instrumental values).

At the initial stages of employment, motivation is supported by interest in the chosen work activity and the opportunity to have a high material income. Young professionals, characterized by an individualistic focus on achieving personal goals and recognition, see an opportunity to meet these needs in work. 
Table 5 Motivational types of manual workers with 39-40 years' experience

\begin{tabular}{|c|c|c|c|}
\hline $\begin{array}{c}\text { Motivational } \\
\text { types of } \\
\text { workers }\end{array}$ & $\begin{array}{l}\text { Sum of } \\
\text { Ranks }\end{array}$ & $\begin{array}{c}\mathrm{X}^{2} \\
\text { Friedman } \\
\text { ANOVA }\end{array}$ & $\begin{array}{c}\text { Wilcoxon } \\
\text { Matched } \\
\text { Pairs Test }\end{array}$ \\
\hline patriotic & 116.50000 & \multirow{5}{*}{$\begin{array}{l}45.69831, \\
p<0.0000\end{array}$} & \multirow{5}{*}{$\begin{array}{l}\text { T-12.5000, } \\
\mathrm{p}<0.036581\end{array}$} \\
\hline instrumental & 79.00000 & & \\
\hline professional & 72.50000 & & \\
\hline economic & 66.00000 & & \\
\hline lumpenized & 37.00000 & & \\
\hline
\end{tabular}

After reaching 10 years of work experience, it becomes important for employees who have reached a certain professional level and become qualified specialists to be able to independently organize not only their own work but also the work of other people. Their motivation is supported by the recognition of their professionalism by colleagues and superiors. Upon reaching 20 years of work at the enterprise, a turning point occurs, characterized by a significant decrease in motivation to work together with the desire to change one's life. At this point, the motivation is based on the principle of "working to the minimum allowed limits", so as not to be dismissed. Probably, if there is a suitable job offer, the employee leaves the company. If such employees continue working activity at the enterprise, having overcome the motivational crisis, they are prepared to work actively again and focused on new activities that allow them to bring as much benefit to the enterprise as possible. As the length of service increases, this motivation persists, supplemented by the willingness to participate in the accompanying socially useful work and the expectation of decent remuneration for their work (Table 6).

Table 6 Work motivation of manual workers with different work experience

\begin{tabular}{|c|c|c|c|}
\hline Work experience & Motivational factors & Values & $\begin{array}{c}\text { Type of } \\
\text { motivation }\end{array}$ \\
\hline 4-5 years & $\begin{array}{c}\text { Need for recognition, self-improvement, } \\
\text { communication, achievement of high goals, } \\
\text { decent remuneration }\end{array}$ & $\begin{array}{c}\text { Interest in the work itself, } \\
\text { demonstration of good breeding }\end{array}$ & Internal motivation \\
\hline $8-10$ years & Need for power & Successful enterprise, self- \\
affirmation & $\begin{array}{c}\text { External positive } \\
\text { motivation }\end{array}$ \\
\hline 19-20 years & Need for change, establishing contacts & $\begin{array}{c}\text { External negative } \\
\text { motivation }\end{array}$ & $\begin{array}{c}\text { External positive } \\
\text { motivation }\end{array}$ \\
\hline 29-30 years & Need for change, socially useful work & Active work, wisdom & $\begin{array}{c}\text { External positive } \\
\text { motivation }\end{array}$ \\
\hline $39-40$ years & Need for decent remuneration, socially useful \\
work
\end{tabular}

\section{CONCLUSION}

This research allows concluding that with the increasing period of employment of manual laborers the following changes of work motivation take place. The internal motivation for labor activity is changed to external. The instrumental motivational type being characteristic of shorter employment periods changes to practical companyoriented and further to lumpenized and patriotic characteristic of longer employment. Individualistic needs change to the need for socially useful work. Terminal values of professional self-realization are replaced by abstract values; instrumental values of communication are replaced by values of a successful enterprise and selfaffirmation, which are later replaced by ethical values.

\section{ACKNOWLEDGMENT}

We express our gratitude to the employees of industrial enterprises who participated in the research.

\section{REFERENCES}

[1] A. Anis Salw, and I. Siti Noor, "A Measurement Model of Teachers' Motivation Factors in Primary Schools", Pertanika journal of social science and humanities. Malaysia. Vol.28(3), pp.1769-1785, January 2020.

[2] D. Shao, D.Jiang, H. Zhang, W. Junfa, W. Guifu, L. Jiyi and L. Jianxia, "Optimal Path of Student Engineering Practical Ability Training for Mechanical Engineering Profession-oriented Master's Degree Education", Advances in Social Science Education and Humanities Research. Atlantis press. Paris. Vol. 322, pp. 271-274. January 2019. [Proceedings of the 2nd international seminar on education research and social science (iserss 2019)].

DOI:https://doi.org/10.2991/iserss-19.2019.72

[3] F. F. Dudyrev, O. A. Romanova, A. I. Shabalin, and I.V. Abankina, Young professionals for the new economy: vocational education in Russia. Moscow: Publishing house of the Higher School of Economics, 
2019, 271 p. DOI: https://doi.org/10.17323/978-5-7598$1937-0$

[4] N.Yu. Romanova, "Project "School- vocational school-enterprise" as a form of network interaction organization in the professional orientation work of an educational organization", Materials of the IV International scientific and practical conference "Professional education: problems, research, innovations". Yekaterinburg, 2017, pp.297-303.

[5] Sh. Jiang, Sh. Liu, Z. Zhou, and L.Hongfa, "Practical Research on the Cooperative Cultivation of "Primary, Master and Industrial" Multidimensional School and Enterprise in Engineering Education of Mechanical Applied Talents", Advances in Social Science Education and Humanities Research. Atlantis Press. Paris. Vol. 322, pp. 368-372. June 2019.

[Proceedings of the 2nd international seminar on education research and social science (iserss 2019)] DOI: https://doi.org/10.2991/iserss-19.2019.96
[6] V.I. Gerchikov, "Labor motivation: concept, identification and management (part 1)", Personality. Culture. Society. Moscow, Vol. 8. No. 3 (31). pp. 222233, September 2020.

DOI:https://doi.org/10.30936/1606-951X

[7] W. Ming-Te, Jiesi Guo, and J.L. Degol, “The Role of sociocultural Factors in Student Achievement Motivation: A Cross-Cultural Review", Adolescent research review. Switzerland. Vol. 5(4), pp.435-450. July 2019. DOI: https://doi.org/10.1007 / s40894-01900124-y

[8] Y. Zhuo, D. Yanbo, H. Shaojia, W. Xiqing, and M. Shi, "A Study on the Student Drain of the Major of Automobile Service Engineering", Advances in Social Science Education and Humanities Research. Atlantis Press. Paris. Vol. 195, pp. 108-11. January 2018.

[Proceedings of the 2018 international seminar on education research and social science (iserss 2018)]. DOI: https://doi.org/10.2991/iserss-18.2018.29 